\title{
APLIKASI PEMANFAATAN TEPUNG KEONG MAS TERFERMENTASI ENZIM PAPAIN DALAM PAKAN SEBAGAI BIOPERMENTOR UNTUK MENINGKATKAN KINERJA PERTUMBUHAN IKAN GABUS (Channa striata)
}

\section{APPLICATION OF THE UTILIZATION OF PAPAIN ENZYME FERMENTED MASK FLOUR IN FEED AS A BIOPERMENTOR TO IMPROVE THE GROWTH PERFORMANCE OF CHANNEL FISH (Channa striata)}

\author{
${ }^{1}$ Andi Khaeriyah, ${ }^{1}$ Nur Insana, ${ }^{1}$ Muhammad Ikbal \\ Fakultas Pertanian, Universitas Muhammadiyah (UNISMUH) Makassar \\ Jalan Sultan Alauddin No. 259, Makassar, South Sulawesi 90221 \\ Telp :+6285255580238/Email :andikhaeriyah@unismuh.ac.id
}

\begin{abstract}
ABSTRAK
Penelitian ini bertujuan untuk menentukan konsentrasi optimal enzim papain yang dapat digunakan pada permentasi keong mas guna meningkatkan kinerja pertumbuhan ikan gabus (Channa striata). Penelitian ini dilaksanakan pada bulan Mei sampai September 2019. Di Balai Benih Ikan Air Tawar Limbung (BBI) Limbung kabupaten Gowa. Pakan yang digunakan adalah pakan pellet berbahan baku keong mas yang dipermentasi dengan enzim papain buah papaya. Penelitian ini menggunakan Rancangan Acak lengkap (RAL) yang terdiri dari 4 perlakuan dan 3 kali ulangan yakni : A 1,5\%, B 2,25\%, C.3\% dan D. Kontrol (0\%). Data yang diperoleh diolah menggunakan Analysis of Varians (ANOVA). Oleh karena hasil yang diperoleh berpengaruh nyata maka dilanjutkan dengan uji Lanjut Duncan. Hasil penelitian menunjukkan bahwa pemberian pakan keong mas terpermentasi enzim papain dengan konsentrasi berbeda memberikan pengaruh yang sangat nyata $(\mathrm{P}<0.05)$ terhadap tingkat kecernaan protein, kecernaan serat, retensi protein, efisiensi pemanfaatan pakan, kandungan albumin, dan pertumbuhan mutlak. Namun tidak memberikan pengaruh yang nyata $(\mathrm{P}>0.05)$ terhadap retensi lemak dan sintasan benih ikan gabus. tingkat kecernaan protein, kecernaan serat, retensi protein, efisiensi pemanfaatan pakan, kandungan albumin, dan pertumbuhan mutlak. tertinggi diperoleh pada perlakuan $\mathrm{B}(2,25 \%)$ dengan nilai masing-masing $(87,66 \%)$, $(91,24 \%),(58,07 \%)(79,05 \%),(9,77 \%)$, (94gr) sedangkan tingkat kecernaan protein, kecernaan serat, retensi protein, efisiensi pemanfaatan pakan, kandungan albumin, dan pertumbuhan mutlak. terendah diperoleh pada perlakuan D (0\%) yaitu $(60,09 \%),(81,72 \%),(32,56 \%),(54 \%) .(7,88 \%)$ dan $(89,11 \mathrm{gr})$. Kualitas air pada media pemeliharaan selama penelitian adalah $26-29^{\circ} \mathrm{C}$, pH 7-8, Oksigen 4-6mg/l dan amonia 0,013-0,11 mg/l.
\end{abstract}

Kata kunci :Enzim papain, Kinerja pertumbuhan, Ikan gabus

\begin{abstract}
This study aims to determine the optimal concentration of the enzyme papain which can be used in the fermentation of golden snails to improve the growth performance of snakehead fish (Channa striata). This research was conducted from May to September 2019. At the Limbung Freshwater Fish Seed Center (BBI) Limbung, Gowa Regency. The feed used was pellet feed made from golden snails which were fermented with the enzyme papain papaya fruit. This study used a completely randomized design (CRD) consisting of 4 treatments and 3 replications, namely: A 1.5\%, B 2.25\%, C.3\% and D. Control (0\%). The data obtained were processed using Analysis of Variance (ANOVA). Because the results obtained had a significant effect, then continued with the Duncan continued test. The results showed that feeding papain enzyme
\end{abstract}


Aplikasi Pemanfaatan Tepung Keong Mas Terfermentasi Enzim Papain........(Andi Khaeriyah)

snails with different concentrations had a very significant effect $(\mathrm{P}<0.05)$ on the level of protein digestibility, fiber digestibility, protein retention, efficiency of feed utilization, albumin content, and absolute growth. However, it did not have a significant effect $(\mathrm{P}>0.05)$ on fat retention and survival of snakehead fish seeds. protein digestibility, fiber digestibility, protein retention, feed utilization efficiency, albumin content, and absolute growth. the highest was obtained in treatment B $(2.25 \%)$ with respective values $(87.66 \%),(91.24 \%),(58.07 \%)(79.05 \%),(9.77 \%),(94 \mathrm{gr})$ while the level of protein digestibility, fiber digestibility, protein retention, feed utilization efficiency, albumin content, and absolute growth. The lowest was obtained in treatment D (0\%), namely (60.09\%), (81.72\%), (32.56\%), (54\%). (7.88\%) and (89.11gr). The quality of water in the maintenance medium during the study was $26-290 \mathrm{C}$, pH 7-8, 4-6mg / 1 oxygen and $0.013-0.11 \mathrm{mg} / 1$ ammonia.

Keyword : Papain enzyme, Growth performance, Fish Cork

\section{PENDAHULUAN}

Ikan gabus (Channa striata) merupakan salah satu komoditas unggulan ikan air tawar yang mudah dibudidayakan dan bernilai ekonomi tinggi karena mengandung albumin. Namun yang menjadi kendala adalah ikan gabus sangat bergantung pada suplai dan kesesuain kebutuhan kandungan nutrisi pakan, untuk menghasilkan pertumbuhan yang optimal ikan gabus memerlukan pakan dengan kadar protein $50 \%$ (Khaeriyah, 2018). Harga pakan dengan kandungan protein tinggi relatif mahal oleh karena sumber protein seperti tepung ikan dan tepung kedelai masih diimpor. Untuk itu beberapa upaya rekayasa pakan telah dilakukan, antara lain dengan mensubstitusi tepung ikan dan tepung kedelai dengan tepung keong mas (Puspita dkk 2016) dan (Khaeriyah dkk, 2018). Namun kendala faktual selanjutnya yang dihadapi adalah rendahnya nilai kecernaan ikan dibanding dengan penggunaan tepung ikan. sehingga berdampak pada rendahnya pertumbuhan. Untuk itu perlu dilakukan permentasi pada keong mas agar protein yang terkandung di dalamnya dapat diurai secara sempurna menjadi asam amino, dan salah satu enzim proteolitik yang dapat melakukan pemecahan ikatan peptida dalam protein adalah enzim papain ( Amaliyah, 2013).
Penelitian tentang pemanfaatan enzim papain sebagai suplemen pakan ikan sudah banyak dilakukan antara lain, Arief dkk, 2015; Mapparimeng, 2016; Sulasih dkk, 2018; Khaeriyah, 2018; Khaeriyah, 2019. Namun demikian belum dilakukan penelitian tentang Substitusi keong mas terpermentasi enzim papain pada pakan untuk meningkatkan kinerja pertumbuhan ikan gabus.

\section{TUJUAN PENELITIAN}

Penelitian ini bertujuan untuk menentukan kadar enzim papain yang optimal digunakan untuk proses permentasi keong mas sebagai bahan baku pakan ikan terhadap kinerja pertumbuhan ikan gabus (Channa striata)

\section{METODE PENELITIAN}

Ikan uji yang digunakan adalah benih ikan gabus dengan bobot \pm 1 g. Ikan gabus yang dijadikan sampel terlebih dahulu diaklimatisasi dengan lingkungan pemeliharaan selama 1 jam kemudian dilakukan adaptasi pakan selama 1 minggu sebelum diberi pakan uji sesuai perlakuan.

Pakan uji yang digunakan pada penelitian ini adalah pakan pellet yang bahan bakunya adalah keong mas terfermentasi enzim papain. Proses pembuatan pakan diawali dengan persiapan bahan baku, fermentasi, pencampuran bahan baku pakan, pencetakan 
pakan dan pengeringan pakan. Pemberian pakan dilakukan secara at satiation 3 kali per hari. Guna mencapai tujuan penelitian yang diinginkan ikan gabus dipelihara selama dua bulan. untuk memperoleh data kuantitatif proximat tubuh ikan gabus dilakukan dengan menggunakan spektrofotometer. Langkah-langkah dalam mendeterminasi proximat tubuh mengikuti petunjuk AOAC (2010). Untuk memperoleh data pertumbuhan dilakukan pengamatan awal dan akhir penelitian. Wadah yang digunakan adalah akuarium berukuran panjang, lebar, dan tinggi masing-masing 50 x 40 x $35 \mathrm{~cm}$. Bagian sisi wadah ditutup dengan plastik hitam, seperti yang terlihat pada Gambar 1.

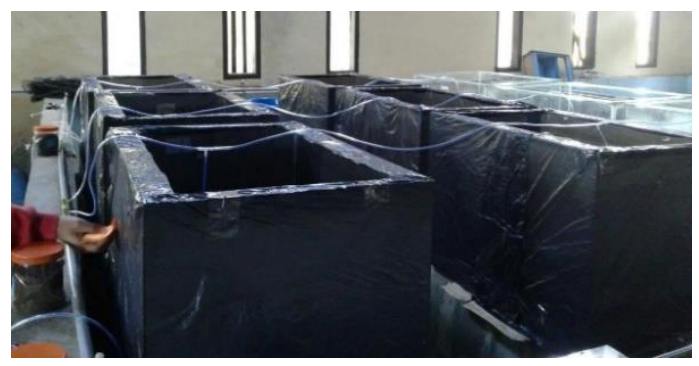

Gambar 1. Wadah Penelitian

\section{Perlakuan dan Rancangan Percobaan}

Penelitian ini menggunakan Rancangan Acak Lengkap (RAL) yang terdiri dari 4(empat) perlakuan dan 3(tiga) kali ulangan. Adapun perlakuannya sebagai berikut :

Perlakuan A: Enzim papain 1,5\%/kg keong mas

Perlakuan B: Enzim papain 2,25\%/kg keong mas

Perlakuan B: Enzim papain 3,00\%/kg keong mas

Perlakuan D: Kontrol

\section{Peubah yang Diamati}

Peubah yang diamati dalam penelitian ini adalah

\section{Kecernaan Nutrien (Kecernaan Protein dan kecernaan Serat Pakan)}

Nilai kecernaan protein/serat pakan dihitung berdasarkan persamaan (Takeuchi, 1988):

$$
\begin{aligned}
\text { Kecernaan Serat } & =\left(\mathbf{1}+\frac{\boldsymbol{a}}{\boldsymbol{a} \prime} \boldsymbol{x} \frac{\boldsymbol{b}}{\boldsymbol{b}}\right) \mathbf{x} \mathbf{1 0 0 \%} \\
\text { Keterangan : } \mathrm{a} & =\% \mathrm{Cr}_{2} \mathrm{O}_{3} \text { dalam pakan } \\
\mathrm{a}^{\prime} & =\% \mathrm{Cr}_{2} \mathrm{O}_{3} \text { dalam feses } \\
\mathrm{b} & =\% \text { serat dalam pakan } \\
\mathrm{b}^{\prime} & =\% \text { serat dalam feses }
\end{aligned}
$$

\section{Retensi Protein dan Retensi Lemak :} untuk mengetahui pertambahan protein, lemak dan energi dilakukan analisis proksimat. Analisis dilakukan pada awal dan akhir penelitian dengan menggunakan metode AOAC (2010). Persentase retensi nutrient dihitung dengan menggunakan rumus takeuchi (1998) sebagai berikut:

$$
\mathrm{RP}=\frac{(\mathrm{Fp}-\mathrm{Ip})}{\mathrm{P}} \times 100 \%
$$

Keterangan :

$\mathrm{Fp}=$ Jumlah Protein tubuh ikan pada waktu akhir penelitian (g)

Ip = Jumlah Protein tubuh ikan pada waktu awal penelitian (g)

$\mathrm{P}=$ Jumlah Protein yang dikonsumsi ikan selama penelitian $(\mathrm{g})$

\section{Efisiensi Pemanfaatan Pakan (EPP)}

Efisiensi pemanfaatan pakan dihitung menggunakan rumus (Tacon, 1987) :

$$
\mathrm{EPP}=\frac{\mathrm{Wt}-\mathrm{Wo}}{\mathrm{F}} \times 100 \%
$$

Keterangan :

$\mathrm{EPP}=$ Efisiensi pemanfaatan pakan $(\%)$

$\mathrm{Wt}=$ Biomassa ikan pada akhir penelitian $(\mathrm{g})$

Wo = Biomassa ikan pada awal penelitian $(\mathrm{g})$

$\mathrm{F}=$ Bobot total pakan selama penelitian $(\mathrm{g})$

\section{Pengukuran kadar albumin}

Pengukuran kadar albumin dilakukan pada awal dan akhir penelitian dengan cara, daging ikan difillet kemudian dilakukan 
perhitungan kandungan albumin dengan menggunakan spektrofotometer.

\section{Pertumbuhan}

Pertumbuhan dihitung dengan menggunakan rumus pertumbuhan mutlak dari Ricker (1979) sebagai berikut :

$$
\mathrm{W}=\mathrm{Wt}-\mathrm{W}_{0}
$$

Pengukuran bobot dilakukan pada awal penelitian, pertengahan dan akhir penelitian. Bobot yang diukur adalah bobot biomassa yang kemudian dirata-ratakan untuk setiap ekot ikan.

\section{Sintasan}

Sintasan benih dihitung dengan rumus (Effendi, 2002),

$$
\mathrm{SR}=\frac{\mathrm{Nt}}{\mathrm{No}} \times 100 \%
$$

Keterangan :

$\mathrm{SR}=$ Sintasan $(\%)$

$\mathrm{Nt}=$ Jumlah ikan pada akhir penelitian (ekor)

$\mathrm{N} 0=$ Jumlah ikan pada awal penelitian (ekor)

Kualitas air diukur dengan menggunakan alat-alat seperti termometer yang digunakan untuk pengukuran suhu, $\mathrm{pH}$ meter yang digunakan dalam pengukuran $\mathrm{pH}$ (derajat keasaman) pada media pemeliharaan, DO meter yang digunakan pada pengukuran DO (oksigen terlarut), dan Water Quality Checker yang digunakan untuk pengukuran kandungan NH3 (amoniak) pada media perlakuan.

\section{Analisis Data}

Kecernaan protein, kecernaan serat, retensi protein, retensi lemak, efisiensi pemanfaatan pakan, kadar albumin, pertumbuhan dan sintasan pada masing-masing perlakuan dianalisis menggunakan sidik ragam (ANOVA) apabila terdapat pengaruh yang nyata maka dilanjutkan degan uji lanjut Duncan selang kepercayaan $95 \%$ (Gazpers, 1991) menggunakan program SPSS versi 24. Adapun kualitas air dianalisis secara deskriptif

\section{HASIL DAN PEMBAHASAN}

\section{Kecernaan Nutrien Benih Ikan Gabus} Nilai rata-rata kecernaan protein dan kecernaan serat pakan benih ikan gabus yang diberi pakan keong mas terfermentasi enzim papain dengan konsentrasi yang berbeda selama penelitian disajikan pada Tabel 1.

Tabel 1. Tingkat kecernaan nutrient pakan benih ikan gabus yang diberi pakan keong mas terfermentasi enzim papain dengan konsentrasi berbeda

\begin{tabular}{lcc}
\hline \multicolumn{1}{c}{$\begin{array}{c}\text { Perlakuan Konsentrasi } \\
\text { Enzim (\%) }\end{array}$} & \multicolumn{2}{c}{ Kecernaan Nutrien Pakan } \\
Kecernaan Protein & Kecernaan Serat \\
\hline Perlakuan A (1,5\% papain) & $76,34 \pm 0,15^{\mathrm{b}}$ & $86,83 \pm 0,19^{\mathrm{b}}$ \\
Perlakuan B (2.25\% papain) & $87,66 \pm 0,43^{\mathrm{a}}$ & $91,24 \pm 0,77^{\mathrm{a}}$ \\
Perlakuan C (3\% papain) & $75,32 \pm 0,51^{\mathrm{b}}$ & $85,44 \pm 0,95^{\mathrm{b}}$ \\
Perlakuan D (kontrol) & $60,09 \pm 0,91^{\mathrm{c}}$ & $81,72 \pm 0,11^{\mathrm{c}}$ \\
\hline
\end{tabular}

Keterangan : Nilai rata-rata pada kolom yang sama dengan huruf superscript berbeda menunjukkan nilai yang berbeda nyata

Berdasarkan hasil analisis ragam substitusi keong mas yang difermentasi enzim papain dengan dosis berbeda memberikan pengaruh yang nyata $(\mathrm{P}<0,05)$ terhadap kecernaan nutrien pakan benih ikan gabus Channa striata.
Hasil uji lanjut Duncan perlakuan pemberian keong mas terfermentasi enzim papain dengan dosis berbeda memperlihatkan bahwa kecernaan protein pakan benih ikan gabus yang disubstitusi keong mas terfermentasi enzim papain dengan dosis $2.25 \%$ sangat nyata $(\mathrm{P}<0.05)$ lebih tinggi 
dibanding substitusi keong mas terfermentasi $1,75 \%, 3 \%$ dan $0 \%$.

Hasil penelitian pada Tabel 1 menunjukkan bahwa pakan berbahan baku keong mas yang difermentasi enzim papain $2,25 \%$ menghasilkan nilai kecernaan nutrien tertinggi dibanding pemberian konsentrasi enzim lainnya. Hal ini disebabkan oleh karena konsentrasi enzim 2,25\% merupakan konsentrasi optimal dan efektif bagi benih ikan gabus untuk pemecahan atau penguraian secara sempurna ikatan peptida protein menjadi ikatan peptida yang lebih sederhana, sehingga pakan yang diberikan dapat tercerna oleh ikan gabus secara lebih sempurna. Sedangkan rendahnya nilai kecernaan protein pada perlakuan fermentasi enzim papain $3 \%$ menunjukkan bahwa enzim dengan konsentrasi tersebut tidak efektif dimanfaatkan oleh benih ikan gabus dalam memecah protein menjadi asam amino, Hal ini disebabkan karena peningkatan dosis enzim papain mampu merusak keseimbangan atau konfigurasi protein sehingga pakan yang diberikan tidak dapat dicerna maksimal oleh ikan. Demikian juga dengan konsentrasi $1,5 \%$ dan $0 \%$ (kontrol), dimana konsentrasi enzim tersebut tidak efektif dalam memecah protein ke dalam bentuk yang lebih sederhanan. Hal ini sesuai dengan hasil penelitian Hutabarat (2016) bahwa konsentrasi enzim 2,25\% merupakan konsentrasi optimal bagi benih ikan lele sangkuriang dalam menghidrolisis protein pakan yang diberikan dibanding dengan konsentrasi papain $(1,125 \% / \mathrm{kg}$ pakan)dan $(3,375 \% / \mathrm{kg}$ pakan $)$

\section{Retensi Protein dan Retensi lemak}

Nilai rata-rata retensi protein dan retensi lemak benih ikan gabus yang diberi pakan keong mas terfermentasi enzim papain dengan konsentrasi yang berbeda disajikan pada Tabel 2.

Tabel 2. Rata-rata nilai retensi protein dan retensi lemak benih ikan gabus yang diberi pakan keong mas terfermentasi enzim papain dengan konsentrasi yang berbeda.

\begin{tabular}{lcc}
\hline \multicolumn{1}{c}{ Perlakuan Konsentrasi } & & Retensi \\
Enzim (\%) & Retensi Protein & Retensi Lemak \\
\hline Perlakuan A (1,5\% papain) & $51,07 \pm 0,15^{\mathrm{b}}$ & $13.04 \pm 0,19^{\mathrm{a}}$ \\
PerlakuanB (2.25\% papain) & $58,07 \pm 0,43^{\mathrm{a}}$ & $13.08 \pm 0,77^{\mathrm{a}}$ \\
Perlakuan C (3\% papain) & $48,04 \pm 0,51^{\mathrm{b}}$ & $13.12 \pm 0,95^{\mathrm{a}}$ \\
Perlakuan D (kontrol) & $32,56 \pm 0,91^{\mathrm{c}}$ & $13,16 \pm 0,11^{\mathrm{a}}$ \\
\hline
\end{tabular}

Keterangan : Nilai rata-rata pada kolom yang sama dengan huruf superscript berbeda menunjukkan nilai yang berbeda nyata

Berdasarkan hasil analisis ragam substitusi keong mas yang difermentasi enzim papain dengan dosis berbeda memberikan pengaruh yang nyata $(\mathrm{P}<0,05)$ terhadap retensi protein, namun tidak berpengaruh nyata terhadap retensi lemak benih ikan gabus. Hasil uji lanjut Duncan memperlihatkan bahwa retensi protein benih ikan gabus yang disubstitusi keong mas terfermentasi enzim papain dengan dosis $2.25 \%$ sangat nyata
$(\mathrm{P}<0.05)$ lebih tinggi $(58,07)$ dibanding substitusi keong mas terfermentasi $1,75 \%$, $3 \%$ dan $0 \%$.

Hasil penelitian pada Tabel 2 menunjukkan bahwa permentasi keong mas dengan konsentrasi enzim $2.25 \%$ menghasilkan nilai

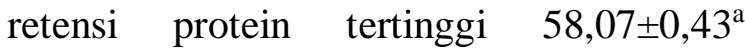
dibandinga perlakuan lainnya. Tingginya nilai retensi protein pakan pada perlakuan fermentasi enzim dosis $2,25 \%$ pada 
penelitian ini berbanding lurus dengan persentase kecernaan protein . Hal ini dikarenakan protein pakan yang tercerna secara efektif dapat dimanfaatkan dan diserap tubuh ikan gabus secara sempurna, sehingga menyebabkan kandungan protein tubuh lebih tinggi dibandingkan dengan perlakuan lainnya. Hal ini sesuai dengan hasil penelitian Khaeriyah dkk (2018) yang menghasilkan konsentrasi 2,25\% merupakan konsentrasi optimal dalam menghasilkan retensi protein. Sedangkan nilai retensi protein yang dihasilkan pada penelitian ini

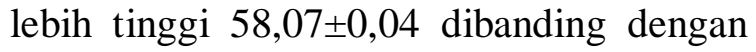
retensi protein yang dihasilkan Khaeriyah, dkk (2018) pada penelitian pemberian pakan keong mas pada benih ikan gabus yang tidak difermentasikan dengan nilai retensi 49,13 $\pm 1,07$.

Berdasarkan hasil penelitian pada (Tabel 2) menunjukkan substitusi keong mas yang difermentasi enzim papain dengan dosis berbeda tidak memberikan pengaruh yang nyata $(p>0.05)$ terhadap retensi lemak benih ikan gabus. Hal ini dikarenakan enzim papain tidak bekerja dalam proses hidrolisis lemak, selain itu kandungan lemak dalam pakan untuk semua perlakuan dalam penelitian ini sama. Hasil penelitian ini sejalan dengan hasil penelitian Khaeriyah dkk (2018), yang memperoleh retensi lemak yang tidak berbeda pada ikan gabus yang diberi pakan suplemen krom yang diinkorporasi melalui jamur Rhyzopus orizae dengan kandungan lemak yang sama namun mengandung kadar protein dan karbohidrat yang berbeda.. Hal tersebut juga sejalan dengan pernyataan Sumarlin dkk (2013) bahwa buah papaya mengandung konsentrasi enzim lypase yang sangat rendah dibanding dengan buah lainnya seperti alpukat dan buah pisang sehingga aktifitas enzimnya juga sangat rendah.

\section{Efisiensi Pakan}

Nilai rata-rata efisiensi pakan benih ikan gabus yang diberi pakan keong mas terfermentasi enzim papain dengan konsentrasi yang berbeda selama penelitian disajikan pada Gambar 2.

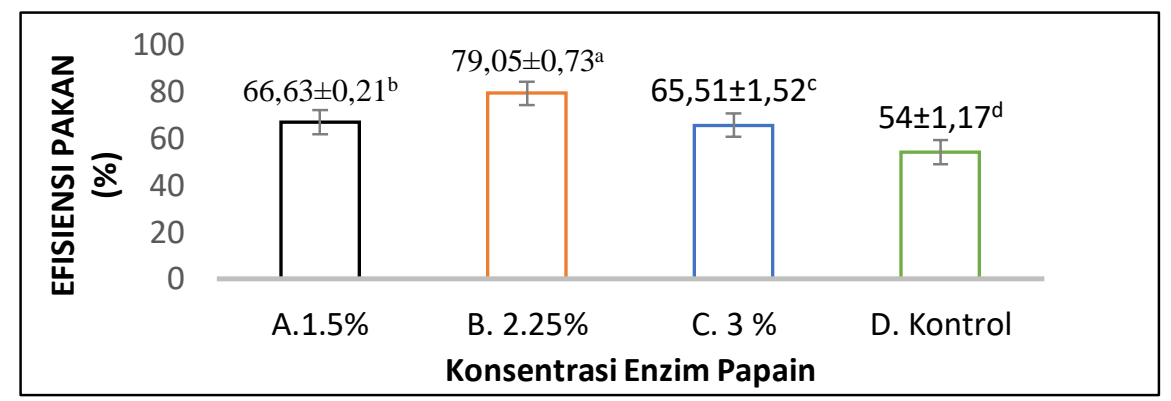

Gambar 2. Efisiensi pakan benih ikan gabus yang diberi pakan keong mas terfermentasi enzim papain dengan konsentrasi berbeda selama penelitian

Analisis ragam menunjukkan bahwa pemberian keong mas terfermentasi enzim papain dalam pakan memberikan pengaruh nyatan $(p<0.05)$ terhadap efisiensi pakan benih ikan gabus. Hasil uji lanjut Duncan memperlihatkan bahwa efisiensi pakan benih ikan gabus yang diberi pakan keong mas terfermentasi enzim papain $2,25 \%$ nyata lebih tinggi dibanding pakan uji lainnya.
Berdasarkan Gambar 2. Nilai efisiensi pakan tertinggi yang dihasilkan pada penelitian ini diperoleh pada perlakuan B konsentrasi enzim 2,25\% yakni 79,05 $\pm 0,73$ dibanding dengan perlakuan A,C dan D (1,5\%,3\% dan $0 \%)$. Hal ini dikarenakan fermentasi keong mas dengan enzim papain 2,25\% merupakan konsentrasi optimal yang efektif menghidrolisis protein menjadi protein dalam bentuk yang lebih sederhana sehingga 
benih ikan gabus dapat mencerna pakan secara maksimal sehingga pakan yang diberikan dapat termanfaatkan secara efisien. Hasil penelitian ini sesuai dengan yang dilaporkan oleh Hastuti (2001) bahwa hidrolisis yang terjadi dengan enzim proteolitik adalah putusnya ikatan peptida dari ikatan substrat dan hidrolisis protein dilakukan oleh enzim endogenus dan dibantu oleh enzim eksogenus dimana enzim hidrolitik berperan sebagai enzim eksogenus.
Adanya penambahan enzim ini membantu menghasilkan asam amino lebih banyak sehingga pakan dikonsumsi dapat termanfaatkan dengan lebih efisien.

\section{Kandungan Albumin}

Nilai rata-rata kandungan albumin benih ikan gabus yang diberi pakan keong mas terfermentasi enzim papain dengan konsentrasi yang berbeda disajikan pada Gambar 3.

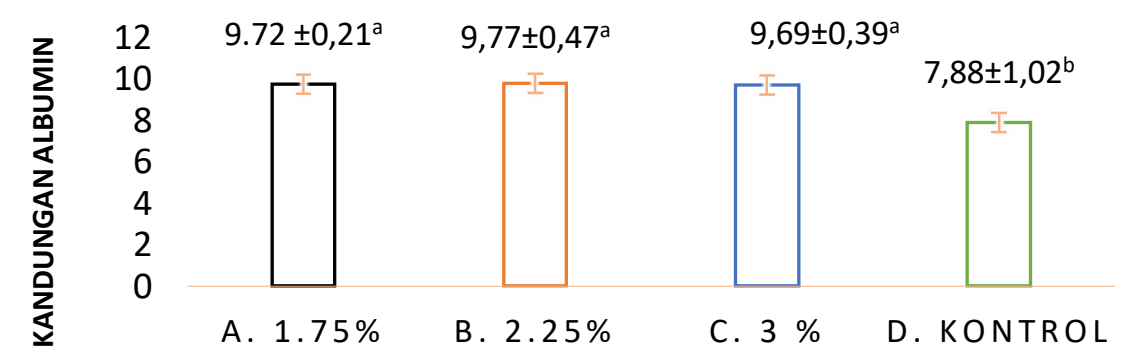

Konsentrasi Enzim Papain

Gambar 3. Tingkat kandungan albumin benih ikan gabus yang diberi pakan keong mas terfermentasi enzim papain dengan konsentrasi berbeda dalam pakan buatan selama penelitian.

Berdasarkan hasil analisis ragam substitusi keong mas yang difermentasi enzim papain dengan dosis berbeda pada pakan buatan selama penelitian memberikan pengaruh yang nyata $(p<0,05)$ terhadap kandungan albumin benih ikan gabus. Hasil uji lanjut Duncan pemberian pakan keong mas terfermentasi enzim papain dengan konsentrasi $1,5 \%, \quad 2,25 \%$ dan $3 \%$ menunjukkan kandungan albumin yang tidak berbeda, namun perlakuan pemberian pakan keong mas tanpa fermentasi (kontrol) menghasilkan kandungan albumin yang nyata lebih rendah dari perlakuan lainnya.

Rendahnya kandungan albumin pada perlakuan kontrol disebabkan karena keong mas yang disubstitusi ke dalam pakan sebelumnya tidak dilakukan fermentasi, sehingga menyebabkan protein tidak dapat dihidrolisis secara sempurna untuk menghasilkan asam amino yang lebih banyak, dan selanjutnya berdampak pada nilai retensi protein yang rendah, sedangkan pada perlakuan pemberian keong terfermentasi enzim papain dengan dosis berbeda menghasilkan kandungan albumin yang lebih tinggi, disebabkan karena pada perlakuan tersebuat enzim papain yang mengandung enzim proteolitik memecahkan protein menjadi peptida yang lebih sederhana sehingga menghasilkan asam amino yang lebih banyak. Hal ini dapat dibuktikan dari tingginya nilai kecernaan protein pakan dan nilai retensi protein, serta nilai efisiensi pakan yang dapat dilihat pada Tabel 1,2 dan 3. 
Hasil penelitian ini sejalan dengan hasil penelitian yang diperoleh Amaliah dkk (2013) bahwa pemberian enzim papain menyebabkan jumlah protein yang disimpan dalam tubuh dan dikonversi menjadi energi yang digunakan untuk pertumbuhan lebih tinggi dibanding dengan perlakuan tanpa enzim papain. Selanjutnya dijelaskan bahwa pemberian dosis papain yang berbeda menghasilkan deposisi protein dalam tubuh yang sama.

\section{Pertumbuhan}

Nilai rata-rata pertumbuhan benih ikan gabus yang diberi pakan keong mas terfermentasi enzim papain dengan konsentrasi yang berbeda disajikan pada Gambar 4. \pm

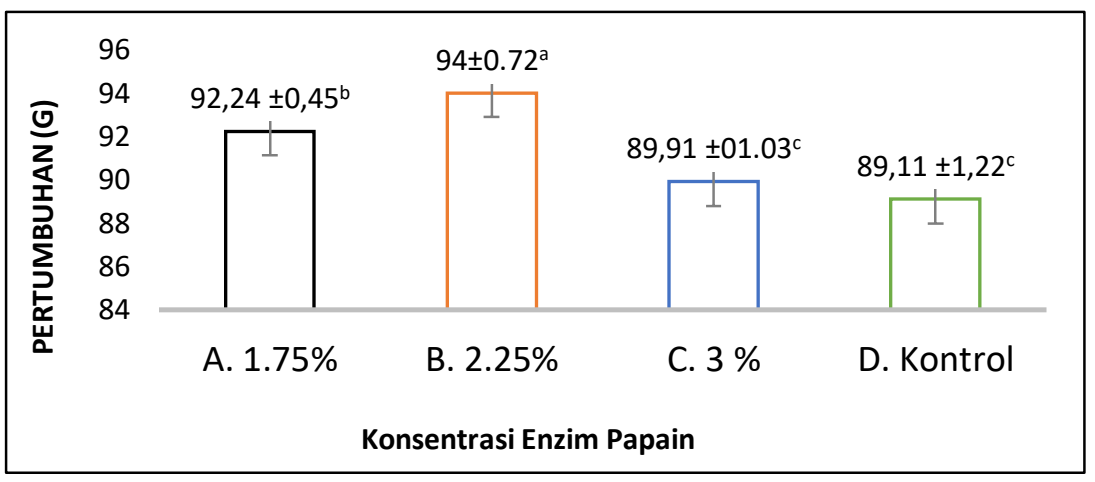

Gambar 4. Pertumbuhan benih ikan gabus yang diberi pakan keong mas terfermentasi enzim papain dengan konsentrasi berbeda dalam pakan buatan selama penelitian.

Berdasarkan hasil analisis ragam substitusi keong mas yang difermentasi enzim papain dengan dosis berbeda memberikan pengaruh yang nyata $(\mathrm{P}<0,05)$ terhadap pertumbuhan benih ikan gabus. Hasil uji lanjut Duncan memperlihatkan bahwa pertumbuhan benih ikan gabus yang disubstitusi keong mas terfermentasi enzim papain dengan dosis $2.25 \%$ sangat nyata $(\mathrm{P}<0.05)$ lebih tinggi $(94,07)$ dibanding substitusi keong mas terfermentasi $1,75 \%, 3 \%$ dan $0 \%$.

Tingginya pertumbuhan yang diperoleh pada perlakuan $\mathrm{B}(2,25 \%)$ menunjukkan bahwa Pemberian enzim papain pada konsentrasi tersebut dapat menghidrolisis protein kompleks menjadi protein lebih sederhana yang menghasilkan asam amino lebih banyak sehingga pakan yang dikonsumsi dapat termanfaatkan secara efisien dan pasokan energi yang terdapat dalam pakan melebihi kebutuhan energi untuk maintenance dan aktivitas tubuh lainnya, sehingga kelebihan energi tersebut selanjutnya dimanfaatkan untuk pertumbuhan. Hal ini sejalan dengan hasil penelitian Khaeriyah dkk, 2018; Johannes 2016; Khaeriyah 2019; yang menyatakan bahwa bahwa sebelum terjadi pertumbuhan, kebutuhan energi untuk maintenance harus terpenuhi terlebih dahulu. Selanjutnya dikatakan bahwa kehadiran enzim dalam pakan buatan dapat membantu dan mempercepat proses pencernaan sehingga nutrien dapat cukup tersedia untuk pertumbuhan.

Rendahnya pertumbuhan yang diperoleh pada perlakuan konsentrasi enzim 1,5\% dan $3 \%$ sejalan dengan hasil penelitian Kazerani dan Shahsavani (2011), bahwa viskositas pencernaan akan meningkat apabila kuantitas enzim terlalu rendah. Daya cerna dan penyerapan nutrisi pakan akan terhambat karena viskositas pencernaan non-pati polisakarida yang berasal dari karbohidrat yang tidak larut sehingga berakibat pada 
rendahnya pertumbuhan. Sedangkan Kelebihan dosis enzim akan berakibat membebaskan monosakarida secara berlebihan, sehingga terjadi hiperglikemia. Hiperglikemia dapat menghambat pertumbuhan. Menurut Putri (2013), hiperglokemia adalah kondisi kadar gula yang tinggi. hiperglikemia dapat melemahkan sekresi insulin dan menambah berat retensi insulin.

\section{Sintasan}

Nilai rata-rata sintasan benih ikan gabus yang diberi pakan keong mas terfermentasi enzim papain dengan konsentrasi yang berbeda disajikan pada Gambar 5.

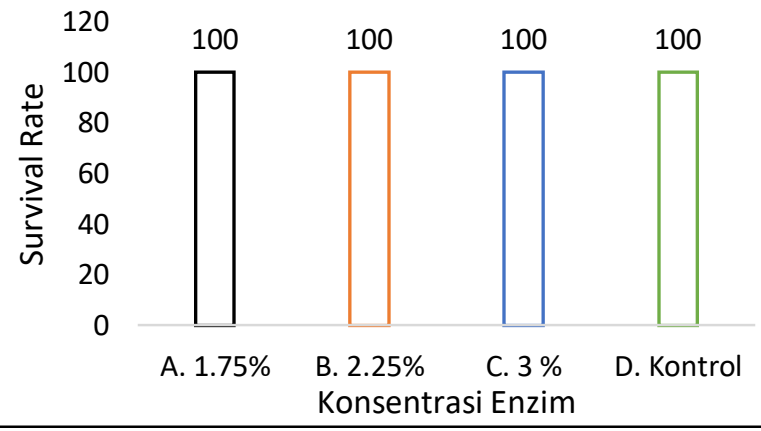

Gambar 5. Sintasan benih ikan gabus yang diberi pakan keong mas terfermentasi enzim papain dengan konsentrasi berbeda

Berdasarkan hasil analisis ragam substitusi keong mas yang difermentasi enzim papain dengan dosis berbeda tidak memberikan pengaruh yang nyata $(\mathrm{P}<0,05)$ terhadap sintasan benih ikan gabus.

\section{Parameter Kualitas Air}

Hasil pengukuran kualitas air media pemeliharaan ikan gabus selama penelitian dapat dilihat pada Tabel 3 .

Tabel 3. Hasil pengukuran parameter kualitas air pada media pemeliharaan ikan gabus selama penelitian

\begin{tabular}{|l|l|l|}
\hline Parameter Kualitas Air & Kisaran & Kelayakan (Pustaka) \\
\hline Suhu & $26-29^{\circ} \mathrm{C}$ & $25-32^{\circ} \mathrm{C}$ (Boyd,1982) \\
\hline Oksigen Terlarut & $5-7,8 \mathrm{mg} / \mathrm{L}$ & $>3 \mathrm{mg} / \mathrm{L}$ (Zonneveld et al. (1991) \\
\hline $\mathrm{pH}$ & $7-8$ & $6,5-9,0$ (Zonneveld et al. (1991) \\
\hline Amonia & $0,013-0,11 \mathrm{mg} / \mathrm{L}$ & $<1 \mathrm{mg} / \mathrm{L}$ (Robinette (1976) \\
\hline
\end{tabular}

Hasil pengukuran parameter kualitas air menunjukkan bahwa nilai parameter kualitas air selama penetian masih berada pada kisaran yang sesuai dan layak untuk budidaya ikan gabus Channa striata.

\section{KESIMPULAN}

1. Substitusi keong mas yang dipermentasi enzim papain dengan konsentrasi $2.25 \%$ menghasilkan kecernaan protein, kecernaan serat, Retensi protein, efisiensi pakan, albumin dan pertumbuhan yang 
Aplikasi Pemanfaatan Tepung Keong Mas Terfermentasi Enzim Papain........(Andi Khaeriyah)

optimal pada benih ikan gabus (Channa striata)

2. Substitusi keong mas yang difermentasi enzim papain dengan konsentrasi yang berbeda tidak memberikan pengaruh pada sintasan benih ikan gabus (Channa striata).

\section{DAFTAR PUSTAKA}

AOAC] Association of Official Analytical Chemist. 2005. Official Methods of Analysis. Virginia: The Association of Official Analytical and Chemist. Arlington (US): AOAC International.

Arief Muhammad1, Mannan A. dan Chaesar A.P. (2015). Penambahan Papain pada Pakan Terhadap Laju Pertumbuhan, Ratio Konversi Pakan, dan Kelulus hidupan Ikan Sidat Angiella bicolor Stadia Elver Jurnal Ilmiah Perikanan dan Kelautan (ISSN: 2085-5842 ). Departemen Manajemen Kesehatan Ikan dan Budidaya Perairan, Fakultas Perikanan dan Kelautan, Universitas Airlangga, Surabaya.

Amalia R., Subandiyono, dan Endang Arini, (2013). Pengaruh Penggunaan Papain Terhadap Tingkat Pemanfaatan Protein Pakan Dan Pertumbuhan Lele Dumbo (Clarias Gariepinus). Program Studi Budidaya Perairan Jurusan Perikanan, Fakultas Perikanan dan Ilmu Kelautan, Universitas Diponegoro Jl. Prof. Soedarto Tembalang-Semarang, Email : rosa.amalia07@yahoo.com.

Effendie M. 2002. Biologi Perikanan. Yayasan Pustaka Nusatama, Yogyakarta, 188 hlm

Kazerani, H.R. and Shahsavani. 2011. The Effect of Suplementation of Feed
With Enzymes on Th Growth of Common Carp (Cyprinus carpio). Iranian Journal of Veterinary Research. 12(2); 127-137

Khaeriyah A. Haryati. T.P. Yusri Mahammad K. (2018). Organic Chromium Supplementation Through Feeding To Increase Influx Of Blood Glucose, Growth And Survival Rate Of Snakehead Fish (Channa striata)

Khaeriyah A. Murni. Syaiful. (2019). Optimasi Pemberian Keong Mas Pada Pakan Untuk Pertumbuhan Dan Sintasan Benih Ikan Gabus (Channa Striata)

Mapparimeng. (2016). Pengaruh penambahan ekstrak daun pepaya (c papaya) pada pakan ikan nila (O. niloticus). Jurnal Agrominansia, 1 (2) Desember 2016.

Idris, A. P. S., \& Indonesia, M. (2015). The Effect Of Different Doses Snails As A Source Of Protein Feed On The Growth And Eel Fish Survival (Anguilla sp.). International Journal of Scientific and Research Publications

Ricker, W.E., 1979. Growth rates and model dalam M.E., brown (Ed). The physiology of fisher. Vol.1. Academi Press. New York. 66 hal.

Sari, W.A.P., Subandiyono dan S. Hastuti. 2013. Pemberian Enzim Papain untuk Meningkatkan Pemanfaatan Protein Pakan dan Pertumbuhan benih Ikan Nila Larasati (Oreochromis niloticus Var.). Universitas Diponegoro, Semarang. Journal of Aquaculture Management and Technology. 2 (1): $1-12$. 
Sulasi, Sri Hastuti, Subandiyono. (2018). Pengaruh Enzim Papain Dan Probiotik Pada Pakan Buatan Terhadap Pemanfaatan Protein Pakan Dan Pertumbuhan Ikan Mas (Cyprinus Carpio). Fakultas Perikanan dan IImu Kelautan - Universitas Diponegoro

Jl. Prof. Soedarto, SH, Tembalang, Semarang 5027 .

Takeuchi, T. 1988. Laboratory WorkChemical Evaluation of Dietary Nutrients. In: Watanabe, T. (Ed.). Fish Nutrition and Mariculture. JICA, Tokyo University Fish. pp. 179-22

Tacon, A. G. J. 1991. Nutrition and feeding of farmed fish and shrimp-A training manual. I. The essential nutrition food and agriculture organizationof the united nations Brasilia, Brazil, $117 \mathrm{pp}$
Vava Fatchurochman, Diana Rachmawati, Johannes Hutabarat. 2017. Pengaruh Kombinasi Pemberian Enzim Papain Pada Pakan Buatan Dan Probiotik Pada Media Pemeliharaan Terhadap Efisiensi Pemanfaatan Pakan, Pertumbuhan Dan Kelulushidupan Ikan Bawal Air Tawar (Colossoma Macropomum). Journal of Aquaculture Management and Technology Volume 6, Nomor 3, Tahun 2017, Halaman 30-39

Putri. I.W. Setiawan M. Jusadi D. 2013. Enzim pencernaan dan kinerja pertumbuhan ikan mas, Cyprinus carpio Linnaeus, 1758) yang diberi pakan dengan penambahan tepung kunyit Curcuma longa Linn. Jurnal Ichtiologi Indonesia. 17(1), 1120/DOI. https;//DOI.org 